\title{
James C. Reed. Radiología del tórax. Patrones y diagnósticos diferenciales
}

\section{Ediciones Amolca}

\author{
Hugo J. Paladini ${ }^{1}$ \\ ${ }^{1}$ Médico coordinador del área Cuerpo en el servicio de Tomografía \\ Computada y Resonancia Magnética en el Hospital Universitario de la \\ Fundación Favaloro, Buenos Aires, Argentina; Jefe del Servicio de \\ Diagnóstico por Imágenes de la Clínica de Nefrología, Urología y \\ Enfermedades Cardiovasculares, Santa Fe, Argentina; Miembro del \\ Comité de Redacción de la Revista Argentina de Radiología.
}

Rev Argent Radiol 2019;83:90-92.

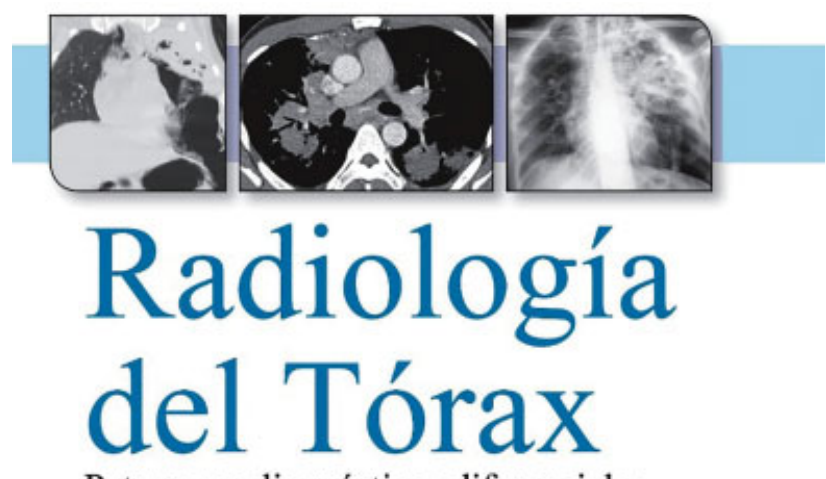

Patrones y diagnósticos diferenciales

\section{Séptima edición}

James C. Reed
Address for correspondence Hugo J. Paladini, MD, Servicio de Tomografía Computada y Resonancia Magnética, Hospital Universitario de la Fundación Favaloro, Buenos Aires, Argentina (e-mail: hugojpaladini@hotmail.com).

radiología convencional y nos invita a descubrir la invaluable información que puede ocultar una placa simple de tórax.

Se trata de la séptima edición del ya clásico libro escrito por el profesor de radiología de la universidad de Louisville, James C. Reed.

Reed repasa, a través de una particular pero pedagógica organización, la patología cardiotorácica visualizada en la radiografía del tórax.

El libro se divide en tres grandes partes. Una primera parte es "Pared torácica, pleura y mediastino", la segunda "Opacidades pulmonares" y, por último, "Anormalidades hiperlucentes". Cada una de ellas se subdivide en capítulos, que suman un total de 24 .

La originalidad reside en la estructura de cada uno de esos capítulos, que favorece al aprendizaje e invita al lector a razonar lo aprendido.

Cada capítulo se dedica a un hallazgo patológico en la placa de tórax, comenzando sin introducción previa con uno o dos casos (radiografías). Luego de revisar cada placa, el lector se encuentra con una serie de preguntas de opción múltiple (orientadas a los casos), para desafiar su conocimiento previo. Continúa, a lo largo del capítulo, desarrollando los diagnósticos diferenciales más importantes que podría presentar el hallazgo radiológico en cuestión, para finalmente resolver las preguntas y el caso planteado inicialmente.

En algunos casos, recurre al correlato con tomografía como herramienta iconográfica para completar la información brindada por la radiografía, sin sacarla del foco de interés.
"La simplicidad de la realización de una radiografía del tórax a menudo lleva a la impresión errónea de que la interpretación debe ser también una tarea simple". Con esa frase, el autor retrata la crisis actual a la que se enfrenta la
DOI https://doi.org/ $10.1055 / \mathrm{s}-0039-1692461$. ISSN 1852-9992.
Copyright (c) 2019, Sociedad Argentina de Radiología. Publicado por Thieme Revinter Publicações Ltda., Rio de Janeiro, Brazil. Todos los derechos reservados.

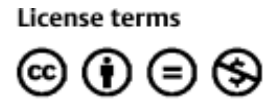


Si bien podría ser desconcertante el hecho de no tener dato clínico alguno de cada caso presentado al comienzo del capítulo (no especifica edad, sexo, clínica ni antecedentes del paciente, solo la placa) a medida que desarrolla los diferenciales, el autor reivindica el valor de cruzar lo que encontramos en la placa y el contexto del paciente. Plantea así la ecuación de: 1) identificar el patrón, 2) enumerar los posibles diferenciales y 3 ) con los datos clínicos y de laboratorio, hacer diagnóstico u orientar los procedimientos adicionales.

Cada capítulo es un ejercicio mental que rescata la pericia necesaria (ya en algunos olvidada) de la correcta, profunda y útil interpretación de una radiografía de tórax simple. Ideal para residentes en niveles iniciales de diagnóstico por imágenes, clínica y neumonología y, por qué no, para refrescar los conocimientos de los ya especialistas. 